\title{
Tantangan Guru Dalam Pembelajaran Daring Pada Masa Pendemi Di SD Negeri 01 Kebandungan Kecamatan Bantarkawung
}

\author{
Juju Ariah Tati Haryati \\ SD Negeri 01 Kebandungan \\ jujuariahth@gmail.com
}

\begin{abstract}
Article History
received 3/12/2020

Abstract

This paper examines the implementation of education policies during the Covid-19 pandemic related to distance learning policies. The distance learning process is a solution that is not yet optimal in its implementation. The purpose of writing this article is to display and desciprtion challenges faced by teachers in the learning process during the pandemic in the SD Negeri 01 Kebandungan, Kecamatan Bantarkawung. This study used a descriptife qualitative. The results of this study prove that, (1) the family economy burdens the problems of the primary needs of parents lives, (2) parental education can affect how parents guide and care for their children while are learning at home, and (3) limited learning resourc as having to have an andorid based phone, data, and signal become obstacles in the learning process.
\end{abstract}

Keywords: teacher, online learning, pandemic, primary school

\begin{abstract}
Abstrak
Tulisan ini mengkaji pelaksanaan kebijakan pendidikan dalam masa pandemi Covid-19 berkaitan dengan kebijakan pembelajaran jarak jauh. Proses pembelajaran jarak jauh merupakan solusi yang dalam pelaksanaannya belum optimal secara keseluruhan. Penelitian ini bertujuan untuk memaparkan dan mendeskripsikan tantangan yang dialami guru dalam proses pembelajaran pada masa pandemi di SD NegeriKebandungan 01, Kecamatan Bantarkawung. Penelitian ini menggunakan pendekatan kualitatif deskriptif. Hasil kajian membuktikan bahwa adanya tantangan dalam guru dalam proses pembelajaran secara daring yaitu, (1) perekonomian keluarga membebani pada masalah-masalah kebutuhan primer kehidupan orang tua, (2) pendidikan orang tua berpengaruh dari bagaimana orang tua membimbing dan mengasuh anaknya selama anak melakukan pembelajaran di rumah, dan (3) keterbatasan sumber belajar seperti harus memiliki telepon berbasis android, paket data dan jaringan sinyal menjadi hambatan dalam proses pembelajaran.
\end{abstract}

Kata kunci: guru, pembelajaran daring, pandemi, sekolah dasar

Social, Humanities, and Education Studies (SHEs): Conference Series https://jurnal.uns.ac.id/shes 


\section{PENDAHULUAN}

Akibat adanya pandemi Covid-19 yang melanda seluruh aspek kehidupan salah satunya adalah di dunia pendidikan yang mengharuskan menjalankan proses kegiatan pembelajaran secara jarak jauh yaitu siswa belajar dan guru mengajar harus tetap berjalan meskipun peserta didik berada di rumah. Akibatnya dalam hal ini pendidik dituntut untuk mendesain pembelajaran dengan memanfaatkan media daring (online). Hal ini sesuai dengan Surat Edaran Nomor 4 Tahun 2020 yang diputuskan oleh Menteri Pendidikan dan Kebudayaan Republik Indonesia mengenai Pelaksanaan Kebijakan Pendidikan dalam Masa Darurat Penyebaran Covid-19. Berbagai inisiatifpun dilakukan untuk memastikan kegiatan belajar mengeajar tetap berjalan dengan lancar sesuai pada koridor pendidikan yang berlaku.

Pembelajaran selama pandemi mengakibatkan perubahan yang luar biasa, seolah seluruh jenjang pendidikan terutama untuk jenjang Sekolah Dasar yang secara tiba-tiba diupayakan untuk melaksanakan pembelajaran secara jarak jauh, (Safarati, dkk., 2020). Hal ini tentu tidak mudah, karena sepenuhnya tidak bisa siap untu melaksanakan hal tersebut. Apalagi untuk jenjang Sekolah Dasar dengan latar belakang anak yang tentunya harus selalu dibimbing secara langsung demi kemajuan pribadi, baik secara kognitif, afektif, maupun psikomotorik. Anak pada jenjang Sekolah Dasar tentu masih membutuhkan suasana belajar yang menyenangkan tanpa ada perasaan tertekan dalam mengaktualisasikan kemampuan dirinya, seperti pada anak usia Sekolah Dasar (6-12 tahun) sebagai tahap perkembangan yang fundamental bagi kesuksesan perkembangan selanjutnya, (Andra \& Cintya, 2021).

Hal di atas tentu adanya berbagai tantangan yang harus dihadapi oleh seorang guru dalam melaksanakan pembelajaran secara daring untuk tetap bisa mengembangkan anak didiknya. Selain orang ua, guru adalah sosok yang bisa menjadikan seorang anak dengan tumbuh kembang yang baik, baik secara fisik, mental, dan kecerdasan. Walaupun dengan adanya teknologi yang bisa membantu dalam kelancaran proses pembelajaran daring tentu guru tetap jadi peran utama dalam proses pembelajaran. Tanpa adanya guru kita tidak akan bisa belajar secara benar. Gurulah yang bertanggung jawab untuk mencapai tujuan pendidikan melalui pembentukan karakter anak yang berbangsa dan berbudaya sebagai penerus bangsa.

Pandemi Covid-19 memang telah memberikan gambaran atas keberlangsungan dunia pendidikan di masa depan melalui bantuan teknologi. Namun, teknologi tetap tidak dapat menggantikan tenaga pendidik dan interaksi belajar antara pelajar dengan pengajar sebab edukasi bukan hanya sekadar memperoleh pengetahuan akan tetapi juga tentang nilai, kerja sama, serta kompetensi. Tentu dalam situasi pandemi saat ini menjadi tantangantersendiri bagi kreativitas setiap individu dalam menggunakan teknologi untuk mengembangkan dunia pendidikan (Nizam, 2020).

Ketika guru bertanggung jawab dalam proses pembelajaran di masa pandemi seperti pada saat ini, tentu ada tantangan tersendiri ketika melakukan hal tersebut. Seperti yang terdapat daalm penelitian yang dilakukan oleh Miftahul (2021) dengan judul "Problematika Pembelajaran Jarak Jauh pada Masa Pandemi Covid-19." Yang menunjukkan bahwa ada hal yang harus diperhatikan dalam pembelajaran jarak jauh ini antara lain sumber daya guru harus ditingkatkan kualitasnya, baik dari segi konten maupun metodologi juga dalam hal pemanfaatan teknologi informasi. Selain itu, peserta didik juga kurang aktif dalam mengikuti pembelajaran jarak jauh ini, baik itu disebabkan jaringan internet yang kurang stabil maupun dari segi penyediaan kuota internet yang terbatas.

Hal diatas juga sejalan dengan apa yang dikatakan oleh Azzahra (2020) bahwa untuk kelancaran dalam pembelajaran jarak jauh, guru tidak cukup hanya memiliki keterampilan teknologi dasar (seperti menggunakan komputer dan tersambung ke internet), tetapi juga pengetahuan untuk menggunakan perangkat rekaman dan perangkat lunaknya, serta metode untuk menyampaikan pelajaran tanpa interaksi tatap 
muka (video pembelajaran yang menarik). Keterampilan tersebut akan diperlukan ketika akan menggunakan platform belajar daring (online). Lebih penting lagi,kesenjangan antara skenario pelatihan dan eksekusi di lapangan perlu untuk diminimalisasi, (Hendayana, 2020).

Dari hal di atas, kebijakan belajar di rumah dilaksanakan dengan tetap melibatkan pendidik dan peserta didik melalui pembelajaran secara daring (jarak jauh) dengan mengandalkan teknologi walaupun banyak kendala atau tantangan di dalamnya. Maka dalam penelitian ini mengenai bagaimana tantangan guru dalam melaksanakan proses pembelajaran daring pada masa pandemi di SD Negeri 01 Kebandungan, Kecamatan Bantarkawung? Dengan tujuan untuk mendeskripsikan dan memaparkan mengenai tantangan guru dalam melaksanakan proses pembelajaran daring pada masa pandemi di SD Negeri 01 Kebandungan, Kecamatan Bantarkawung.

\section{METODE}

Metode penelitian ini adalah penelitian kualitatif, penelitian yang menghasilkan data deskriptif berupa kata-kata tertulis atau lisan dari orang-orang dan perilaku yang dapat diamati (Tanzeh, 2011). Peneliti sebagai instrumen kunci dan hasil penelitian lebih menekankan makna daripada generalisasi. Peneliti mengambil jenis penelitain ini dengan alasan untuk mendeskripsikan dan memaparkan data tentang problematika pembelajaran jarak jauh pada masa pandemi covid-19 di jenjang Sekolah Dasar (SD) Kebandungan 01, Kecamatan Bantarkawung. Jenis penelitian yang digunakan dalam penelitian ini adalah desain penelitian yang bersifat deskriptif kualitatif. Penelitian deskriptif kualitatif adalah rancangan penelitian yang menggambarkan data penelitian secara objektif.

Dalam penelitian ini, peneliti menggambarkan atau mendeskripsikan tantangan pembelajaran daring di masa pandemi. Penerapan desain ini dilakukan dengan mengumpulkan data, mengelolah, dan menyajikan data secara objektif. Teknik pengumpulan data dalam penelitian ini ada tiga yakni teknik observasi, dokumentasi, dan wawancara. Berdasarkan teknik pengumpulan data yang digunakan, maka instrumen dalam penelitian ini adalah berhubungan dengan tantangan pembelajaran daring pada masa pandemi di SD Negeri Kebandungan 01, Kecamatan Bantarkawung. Instrumen penelitian yang dimaksud adalah a) observasi yang dilakukan secara online untuk mengamati keadaan secara tidak langsung dalam proses pelaksanaan pembelajaran; dan b) alat dan aplikasi pendukung (laptop, smartphone, google classroom, google formulir) yang digunakan untuk mendapatkan data berdasarkan teknik observasi dan/atau wawancara; dan c) berupa dokumen yang bersangkutan dengan pembelajaran yang diminta secara langsung kepada guru. Berdasarkan teknik pengumpulan data yang digunakan, maka instrumen dalam penelitian ini adalah berhubungan dengan tantangan guru dalam pembelajaran daring pada masa pandemi di SD Negeri Kebandungan 01, Kecamatan Bantarkawung.

\section{HASIL DAN PEMBAHASAN}

Subyek pada study ini adalah siswa kelas 5 SD Negeri Kebandungn 01 yang terdiri dari 10 anak tersebut terdapat 6 anak laki dan 4 anak perempuan. Untuk survey dilakukan dengan mempergunakan angket.

Tabel 1. Data Siswa SD Negeri Kebandungn 01

\begin{tabular}{clccc}
\hline No. & \multicolumn{1}{c}{ Nama } & Jenis Kelasmi & Usia & Kelas \\
\hline 1 & Dio Zulfahri & Laki - Laki & 11 Tahun & V \\
2 & Refan Shadiq & Laki - Laki & 11 Tahun & V \\
3 & Wully Astia & Perempuan & 11 Tahun & V \\
\hline
\end{tabular}




\begin{tabular}{cllll}
\hline 4 & Livia Anggraeni & Perempuan & 11 Tahun & V \\
5 & Seno Rohmansyah & Laki - Laki & 11 Tahun & V \\
6 & Dio Zulfahri & Laki - Laki & 11 Tahun & V \\
7 & Julian Akbar & Laki - Laki & 11 Tahun & V \\
8 & Sehu Ardian Syah & Laki - Laki & 11 Tahun & V \\
9 & Almira Damayanti & Perempuan & 11 Tahun & V \\
10 & Jeany Nasfik & Perempuan & 11 Tahun & V \\
\hline
\end{tabular}

$$
\text { Nilai }=\frac{\Sigma \text { skor nilai yang diperoleh }}{\Sigma \text { skor maksimal }} \times 100 \%
$$

Respon dari siswa mengenai pembelajaran daring ketika berlangsung, dapat dilihat melalui lembar angkat yang sudah diisikan oleh siswa.

$$
\mathrm{P}=\frac{F}{N} \times 100 \%
$$

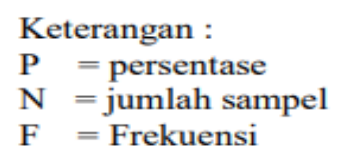

Berdasarkan analisa data, bab ini akan membahas hasil observasi yang dilakukan pada hari kamis 11 Juni 2020 di SD Kebandungan 01. Observasi dilakukan pada 10 anak yang mana dari 10 anak tersebut terdapat 6 anak laki dan 4 anak perempuan. Angket respon siswa diberikan sesaat setelah pembelajaran.

Tabel 2. Data aspek yang diamati dan respon siswa

\begin{tabular}{|l|l|l|l|}
\hline No & \multicolumn{1}{|c|}{ Aspek yang Diamati } & \multicolumn{2}{c|}{ Respon Siswa } \\
\cline { 3 - 4 } & & \multicolumn{1}{|c|}{ Ya } & \\
\hline 1. & $\begin{array}{l}\text { Apakah anda setuju jika pembelajaran } \\
\text { berbasis online diterapkan di sekcolah } \\
\text { pada masa pandemi ? }\end{array}$ & & \\
\hline 2. & $\begin{array}{l}\text { Apakah dengan pembelajaran berbasis } \\
\text { online kamu dapat memahami materi ? }\end{array}$ & & \\
\hline 3. & $\begin{array}{l}\text { Apakah anda dapat mengoprasikan } \\
\text { aplikasi pembelajaran online ? }\end{array}$ & & \\
\hline 4. & $\begin{array}{l}\text { Apakah pembelajaran online sangat } \\
\text { menyenangkan ? }\end{array}$ & & \\
\hline 5. & $\begin{array}{l}\text { Apakah anda mengalami permasalahan } \\
\text { dalam pembelajaran online ? }\end{array}$ & & \\
\hline 6. & $\begin{array}{l}\text { Apakah orang tua ikut memberikan } \\
\text { support yang baik pada saat } \\
\text { pembelajaran online? }\end{array}$ & & \\
\hline 7. & $\begin{array}{l}\text { Apakah orang tua memberikan fasilitas } \\
\text { saat pembelajaran online? }\end{array}$ & & \\
\hline 8. & $\begin{array}{l}\text { Apakah orang tua ikut memberikan } \\
\text { motivasi agar anda giat dalam belajar ? }\end{array}$ & & \\
\hline 9. & $\begin{array}{l}\text { Apakah materi yang di sampaikan guru } \\
\text { melalui online sudah tersampaikan } \\
\text { dengan baik dan tepat ? }\end{array}$ & & \\
\hline 10. & $\begin{array}{l}\text { Apakah tugas yang diberikan oleh guru } \\
\text { sudah sesuai dengan buku tematik siswa } \\
\text { ? }\end{array}$ & & \\
\hline
\end{tabular}

Berdasarkan observasi dengan sepuluh siswa kelas 5 SD. Siswa tidak setuju akan adanya pembelajaran online akan tetapi ada beberapa siswa yang bisa memahami 
dalam pembelajaran online tersebut. Dalam pengoprasian aplikasi banyak siswa yang kurang memahami dalam penggunaanya akan tetapi ada siswa yang bisa memahami karena masih awamnya para siswa dengan aplikasi tersebut yang tentunya jarang bahkan belum pernah di terapkan pada tingkat sekolah dasar. Dalam pembelajaran online mayoritas siswa memberikan pernyataan bahwa ada permasalahan yang terjadi akan tetapi ada beberapa anak yang tidak mengalami permasalahan baik di jaringan maupun tata cara penggunaan. Siswa juga menjelaskan bahwa orang tua juga kurang mensuport siswa untuk belajar secara online.Dalam pembelajaran guru sudah maksimalkan dengan mengirimkan tugas melalui WAG sehingga memudahkan siswa dalam belajar. Berdasarkan angket siswa mengatakan bahwa pembelajaran online tidak berjalan dengan baik kepada siswa.

Tabel 3. Angket Respon

\begin{tabular}{|c|c|c|c|c|c|}
\hline \multirow[t]{2}{*}{ No. } & \multirow{2}{*}{ Aspek yang di amati } & \multicolumn{2}{|c|}{ Respon siswa } & \multicolumn{2}{|c|}{ Presentasi } \\
\hline & & $\mathrm{Ya}$ & Tidak & Ya & Tidak \\
\hline 1 & $\begin{array}{l}\text { Apakah anda setuju } \\
\text { jika pembelajaran } \\
\text { berbasis online } \\
\text { diterapkan disekolah } \\
\text { pada masa pandemi? }\end{array}$ & 0 & 10 & 0 & 100 \\
\hline 2 & $\begin{array}{l}\text { Apakah dengan } \\
\text { pembelajaran berbasis } \\
\text { online kamu dapat } \\
\text { memahami materi? }\end{array}$ & 1 & 9 & 10 & 90 \\
\hline 3 & $\begin{array}{l}\text { Apakah anda dapat } \\
\text { mengoprasikan } \\
\text { aplikasi pembelajaran } \\
\text { online? }\end{array}$ & 1 & 9 & 10 & 90 \\
\hline 4 & $\begin{array}{l}\text { Apakah orangtua ikut } \\
\text { memberikan support } \\
\text { yang baik pada saat } \\
\text { pembelajaran online? }\end{array}$ & 1 & 9 & 10 & 90 \\
\hline 5 & $\begin{array}{l}\text { Apakah orangtua } \\
\text { memberikan motivasi } \\
\text { agar anda giat dalam } \\
\text { belajar? }\end{array}$ & 0 & 10 & 0 & 10 \\
\hline 6 & $\begin{array}{l}\text { Apakah pembelajaran } \\
\text { online } \\
\text { sangatmenyenangkan? }\end{array}$ & 1 & 9 & 10 & 90 \\
\hline 7 & $\begin{array}{l}\text { mengalami } \\
\text { permasalahan dalam } \\
\text { pembelajaran online }\end{array}$ & 9 & 1 & 90 & 10 \\
\hline 8 & $\begin{array}{l}\text { Apakah materi yang } \\
\text { disampaikan oleh guru } \\
\text { melalui online sudah } \\
\text { tersampaikan dengan } \\
\text { baik dan benar? }\end{array}$ & 1 & 9 & 10 & 90 \\
\hline 9 & $\begin{array}{l}\text { Apakah tugas yang } \\
\text { disampaikan guru } \\
\text { sudah sesuai dengan } \\
\text { buku tematik? }\end{array}$ & 9 & 1 & 90 & 10 \\
\hline
\end{tabular}




\begin{tabular}{ccccc}
\hline Apakah orang tua & & & & \\
$\begin{array}{l}\text { membeikan fasilitas } \\
\text { dalam pembelajaran }\end{array}$ & 1 & 9 & 10 & 90 \\
online? Jumlah & 24 & 76 & 240 & 760 \\
Rata - rata & 2,4 & 7,6 & 24 & 76 \\
\hline
\end{tabular}

Adapun beberapa tantangan yang dirasakan guru dalam melaksanakan proses pembelajaran daring di SD Negeri 01 Kebandungan, Kecamatan Bantarkawung yang menjadi hambatan dalam melaksanakan proses pembelajaran selama masa pandemi. Berikut penjelasan dari beberapa tantangan tersebut.

1. Perekonomian Keluarga

Pendidikan memiliki peranan yang sangat penting bagi kemajuan suatu bangsa. Oleh karena itu, pendidikan harus terus menerus diperbaiki baik dari segi kualitas maupun kuantitasnya. Adanya pendidikan dasar 9 tahun menunjukkan bahwa pemerintah berusaha untuk meningkatkan mutu pendidikan. Tujuan dari pendidikan dasar yaitu memberikan bekal kemampuan dasar kepada peserta didik untuk mengembangkan kehidupannya sebagai pribadi, anggota masyarakat, warga negara, dan anggota umat manusia, serta mempersiapkan peserta didik untuk mengikuti pendidikan menengah. Pendidikan tidak hanya cukup sampai pada tingkat dasar saja tetapi masih ada jenjang pendidikan di atasnya berupa pendidikan menengah yang harus ditempuh oleh siswa. Seiring dengan berjalannya waktu dan pembangunan di bidang pendidikan, peranan keberlanjutan sekolah tentu sangat penting untuk menyiapkan peserta didik menjadi anggota masyarakat yang memiliki perkembangan yang signifikan dan mengembangkan dan atau menciptakan ilmu pengetahuan secara mendalam lagi.

Namun pada kenyataannya tidak semua lulusan SD melanjutkan pendidikan ke jenjang selanjutnya, mereka (siswa) masih ada yang memutuskan untuk diam di rumah atau bermain-main saja. Hal ini disebabkan karena masih ada orang tua di Desa Kebandungan, Kecamatan Bantarkawung secara ekonomi kurang mampu. Mayoritas mata pencaharian orang tua yaitu bertani mereka hanya menghasilkan uang dari bertani, sehingga banyak orang tua yang masih belum berfikir maju. Orang tua yang terlalu sibuk dan takut akan hal bahwa anaknya bisa melanjutnya sekolah atau tidak ini menimbulkan pemikiran yang tidak mendukung kemajuan anak. masih banyak orang tua di Desa Kebandungan yang belum mampu untuk meningkatkan kualitas anak dengan meneruskan pendidikan anak ke jenjang-jenjang selanjutnya.

Orang tua yang hanya sibuk bercocok tanam karena adanya keterbatasan dalam pencarian nafkah untuk biaya makan sehari-hari dapat mempengaruhi keberlanjutan dapat anak untuk sekolah pada jenjang pendidikan yang lebih tinggi karena dalam hal ini tentu dibutuhkan adanya sarana dan kelengkapan yang memadai. Seperti dalam pembelajaran jarak jauh saat ini tentu diperlukan teknologi, yaitu telepon genggam dan paket kuota internet untuk memenuhi sarana dan kelengkapan dalam proses pembelajran tersebut tentu diperlukan dana. Masalah ketersediaan dana untuk melanjutkan sekolah berkaitan erat dengan kondisi sosial dan kondisi ekonomi orang tua. Kondisi sosial dan kondisi ekonomi orang tua merupakan salah satu faktor eksternal timbulnya motivasi melanjutkan pendidikan anak. tentu dalam hal ini, motivasi akan memberikan suatu dorongan atau semangat untuk bertingkah laku dalam melakukan kegiatan bagi seseorang untuk mencapai suatu tujuan yang dikehendaki, tanpa motivasi maka aktivitas hidup seseorang akan menurun.

Keadaan sosial ekonomi keluarga tentulah berpengaruh terhadap perkembangan anak-anak, apabila kita perhatikan bahwa dengan adanya perekonomian yang cukup, lingkungan material yang dihadapai anak di dalam keluarganya itu lebih luas, ia mendapat kesempatan yang lebih luas untuk mengembangkan bermacam- macam 
kecakapan yang tidak dapat ia kembangkan apabila tidak ada prasarananya. Hubungan orang tuanya hidup dalam status sosial ekonomi serba cukup dan kurang mengalami tekanan-tekanan fundamental seperti dalam memperoleh nafkah hidupnya yang memadai. Orang tuanya dapat mencurahkan perhatian yang lebih mendalam pada pendidikan anak-anaknya apabila ia tidak dibebani dengan masalah-masalah kebutuhan primer kehidupan manusia.

2. Pendidikan Orang Tua

Proses pembelajaran jarak jauh (PJJ) selama masa pandemi covid-19 ini seharusnya tetap dapat mengakomodasi kebutuhan belajar siswa untuk mengembangkan bakat dan minat sesuai dengan jenjang pendidikannya. Namun untuk mewujudkan hal tersebut diperlukan upaya orang tua dalam menemani anak selama pembelajaran jarak jauh. Karena pada hakikatnya, lingkungan yang sangat memengaruhi tumbuh kembangnya anak adalah keluarga dan latar belakang tingkat pendidikan orang tua. Lingkungan yang terdekat dengan anak adalah keluarga, faktor latar belakang tingkat pendidikan orang tua merupakan sesuatu yang besar pengaruhnya terhadap perkembangan anak. akan tetapi, mayoritas penduduk di Desa Kebandungan, Kecamatan Bantarkawung adalah lulusan tingkat Sekolah Dasar bahkan banyak pula yang tidak lulus dari jenjang Sekolah Dasar, hal inilah mengakibatkan orang tua merasa keberatan dalam mengajarkan anak mengenai materi-materi anak yang diajarkan dari sekolah.

Selain itu, rendahnya pendidikan anak dapat juga berpengaruh dari bagaimana orang tua membimbing dan mengasuh anaknya selama anak melakukan pembelajaran di rumah. Latar belakang tingkat pendidikan orangtua ini berkorelasi positif dengan cara mereka mengasuh anak, sementara pengasuhan anak berhubungan dengan perkembangan anak. Hal ini berarti makin tinggi pendidikan terakhir orangtua akan makin baik pula cara pengasuhan anak dan akibatnya perkembangan anak terpengaruh berjalan secara positif. Sebaliknya makin rendah tingkat pendidikan orangtua akan kurang baik dalam mengasuh anak, sehingga perkembangan anak berjalan kurang menguntungkan.

Peran ibu memang sangat mempengaruhi perkembangan anak selama pembelajaran di rumah. akan tetapi, banyak orang tua yang terlalu sibuk dengan pekerjaanya sendiri. Seperti mereka terlalu fokus bekerja membereskan rumah, adapula orang tua yang meninggalkan anak ke luar kota demi mencari nafkah untuk menyekolahkan anaknya, adapula orang tua yang sibuk mencari nafkah dengan bertani (bercocok tanam) di sawah sehingga hal inilah membuat seorang anak bisa terlantar karena seorang ibu yang tidak sepenuhnya memperhatikan anak dan membimbing anak selama proses pembelajaran daring. Padahal anak usia 7-10 tahun pada jenjang tingkatan Sekolah Dasar masih perlu dituntun untuk melakukan suatu hal apapun, terutama ketika melakukan proses pembelajaran di rumah.

Seorang ibu dalam mengajarkan pelajaran sekolah pada anak harus mengetahui gaya belajar, seperti apakah gaya belajar yang cocok digunakan dalam pengajaran kepada anak. Maka dari itu, gaya belajar sangat penting diketahui oleh orangtua. Hubungannya dengan latar belakang tingkat pendidikan orangtua dengan gaya belajar, yaitu orangtua terutama ibu yang mempunyai latar belakang tingkat pendidikan lebih baik maka akan mengetahui gaya belajar seperti apakah yang tepat dalam pengajaran anak, tetapi sebaliknya orangtua yang mempunyai latar belakang tingkat pendidikan kurang baik maka akan cenderung tidak memerhatikan gaya belajar apakah yang tepat digunakan dalam pengajaran.

Rendahnaya pendidikan orang tua juga mengakibatkan gagalnya pemahaman teknologi di zaman sekarang bagi sekelompok keluarga. Padahal dalam pembelajaran daring pada saat ini, ketika anak belum paham tentang teknologi yang digunakan dalam pembelajaran yaitu telepohon ganggan yang digunakan selama pembelajaran tentu seharusnya orang tua yang membimbing dalam menggunakannya. Akan tetapi, masih 
banyak orang tua yang tidak paham dengan teknologi terutama dalam penggunaan telepon genggam yang dipenuhi dengan berbagai aplikasi pembelajaran.

Orang tua biasanya menyuruh kakak, keluarga lainnya, atau bahkan tetangga untuk membantu anaknya dalam melakukan pembelajaran daring menggunakan telepon genggam. Sehingga ketika ada informasi dari guru seperti penugasan orang lainlah yang menginformasikan kepada orang tua tersebut. Maka, dalam hubungan latar belakang tingkat pendidikan orang tua terutama ibu dengan hasil belajar sangat berpengaruh sekali, yaitu jika pendidikan terakhir orangtua baik maka akan mengarahkan pada kebiasaan belajar yang baik dan mengarahkan pada gaya belajar yang terarah. Hal ini mengakibatkan hasil belajar siswa meningkat, sebaliknya jika pendidikan terakhir orangtua cenderung kurang maka akan lebih cuek dan tidak mau tahu atas permasalahan yang ada di dalam sekolah mengenai hasil belajar siswa yang cenderung kurang.

3. Keterbatasan Sumber Belajar

Dalam melaksanakan pembelajaran daring dengan berbagai keterbatasan kemampuan, sarana dan prasarana berupa handphone, laptop dan jaringan bagi guru dan peserta didik serta kemampuan yang masih terbatas dalam pemanfaatan teknologi membuat pelaksanaan pembelajaran daring harus tetap diupayakan berjalan agar proses transformasi ilmu pengetahuan kepada peserta didik tidak terganggu. Guru sebagai ujung tombak pendidikan melakukan berbagai upaya seperti menerapkan pembelajaran daring melalui media Group Whatsapp, Google Classroom, Moodle, dan aplikasi belajar online lainnya. Untuk pembelajaran secara sinkronus guru juga memanfaatkan media Google Meet, Zoom Cloud Meeting, Cisco Webex dan lain sebagainya. Saat ini banyak sekali sumber belajar online serta konten ilmu yang terdapat di internet.

Pemanfaatan berbagai media pembelajaran daring yang diolah sesuai dengan kemampuan dan keinginan guru. Tuntutan guru tidak hanya secara akademis tetapi juga kemampuan untuk berkomunikasi yang harus dilakukan dalam pembelajaran daring eperti pada media pembelajaran Google Classroom, Moodle dan Group Whatsapp, guru mengirimkan materi pembelajaran, link video pembelajaran, tugas serta sebagai media komunikasi untuk melaksankan proses pembimbingan dan pendampingan kepada peserta didik. Kendala yang dihadapi peserta didik dalam pembelajaran daring yang terjadi pada peserta didik juga ada pada guru seperti tidak memiliki android, paket data dan jaringan sinyal. Kendala tersebut bisa menjadi hambatan dalam proses pembelajaran. Namun guru tentu memaklumi keadaan tersebut dan memberikan solusi dan jalan keluar terhadap permasalahan yang dihadapi kepada peserta didik agar peserta didik tetap bisa mengikuti proses pembelajaran. Tugas dapat diambil dan dikumpulkan disekolah saat kondisi aman dan tetap mematuhi protokol kesehatan. Gangguan jaringan atau sinyal dengan memberikan rentang waktu pengerjaan yang lebih lama sehingga pengerjaan tugas tidak menjadi beban berat.

Problem psikologis peserta didik yang terbiasa belajar bertatap muka langsung dengan guru-guru mereka, bermain dengan teman sebaya dan keisengan serta kegembiraan lain yang dirasakan peserta didik di sekolah. Selain problema sistem yang belum familier, problem psikologis yang dialami peserta didik dan juga orang tua pada umumnya. Juga sedikitnya ada beberapa problem terkait pembelajaran daring ini, antara lain problem keterbatasan penguasaan teknologi, baik dikalangan pendidik, maupun peserta didik. Masih banyak ditemukan pendidik-pendidik di negeri ini yang belum akrab dengan teknologi komputer, termasuk peserta didik, juga masih banyak yang belum mampu secara maksimal menggunakan media daring yang dirancang dengan teknologi informatika.

Dengan berbagai keterbatasan dalam situasi pandemi Covid 19 menjadi tantangan seorang guru untuk terus mau belajar dan berlatih pembelajaran secara daring. Disamping itu guru harus mampu menghadirkan pembelajaran yang menyenangkan dan 
inovatif untuk mengatasi kesulitan belajar yang dihadapi serta kolaborasi media pembelajaran agar pembelajaran tidak monoton dan tetap bisa menghadirkan suasana pembelajaran interaktif antara guru dan peserta didik. Keterbatasan dalam aksesibilitas internet, perangkat keras (hardware) dan perangkat lunak (software), serta pembiayaan sering menjadi habatan dalam memaksimalkan sumber-sumber belajar online. Terdapat banyak ekses bagi keberlangsungan pendidikan yang disebabkan oleh pandemi Covid19. Pertama adalah dampak jangka pendek, yang dirasakan oleh banyak keluarga di Indonesia baik di kota maupun di desa. Di Indonesia banyak keluarga yang kurang familier melakukan sekolah di rumah. Bersekolah di rumah bagi keluarga Indonesia adalah kejutan besar khususnya bagi produktivitas orang tua yang biasanya sibuk dengan pekerjaannya di luar

\section{SIMPULAN}

Guru dalam konteks pendidikan mempunyai peranan yang besar dan strategis. Hal ini karena guru yang berada di barisan terdepan dalam pelaksanaan pendidikan. Sebagai praktisi, guru harus dituntut untuk menyelaraskan antara perubahan zaman yang ditandai dengan kecanggihan teknologi dengan nilai-nilai budi pekerti. Akan tetapi, banyak tantangan ketika proses pembelajaran dilakuakn secara daring (dalam jaringan). Seperti adanya kendala-kendala yang melatarbelakinginya, baik dari faktor orang tua maupun lingkungan. Proses pembelajaran jarak jauh yang dilaksanakan saat ini belum dapat disebut sebagai kondisi belajar yang ideal, melainkan kondisi darurat yang harus dilaksanakan. Masih terdapat berbagai kendala sehingga semua pembelajaran dapat optimal. Pemerintah bekerja sama dengan berbagai pihak terkait melakukan berbagai upaya untuk dapat mengatasi permasalahan yang terjadi dalam pembelajaran daring, baik dari sisi regulasi, peningkatan kesiapan pendidik, serta perluasan jaringan dan akses sumber belajar, agar dapat berjalan secara efektif dan efisien. Namun demikian, upaya tersebut perlu terus ditingkatkan agar optimalisasi pembelajaran daring tidak hanya untuk kondisi darurat seperti saat ini tetapi juga untuk dilaksanakan dalam situasi normal sesuai dengan kebutuhan belajar. Pemerintah terus berupaya mendorong sinergitas berbagai sektor terkait agar upaya peningkatan kualitas pendidikan, baik dalam masa darurat Covid-19 maupun penyelenggaraan pendidikan keberlanjutan di masa depan dapat dioptimalkan.

\section{DAFTAR PUSTAKA}

Andra. Y., Cintya. N.I. (2021). "Keterlibatan Orang Tua dalam pembelajaran Bahasa Indonesia di Masa Pandemi pada Siswa SD Negeri 02 Pengarasan, Kecamatan Bantarkawung." Jurnal Metalingua: Pendidikan Bahasa dan Sastra indonesia. Vol. 06, No. 01, Hal. 11-18.

Azzahra, N.F. (2020). Mengkaji Hambatan Pembelajaran Jarak Jauh di Indonesia di Masa Pandemi Covid-19. Jakarta: Center for Indonesian Policy Studies (CIPS).

Hendayana. (2020). Tantangan dunia Pendidikan di Masa Pandemi. Kemendikbud.co.id Direktorat Jendral Pendidikan Tinggi Kementrian Pendidikan, Kebudayaan, Riset, dan Teknologi.

Miftahul. (2021). "Problematika Pembelajaran Jarak Jauh Pada Masa Pandemi Covid19." Jurnal Pendidikan Agama Islam. Vol. 02, No. 01, Hal. 208-218.

Nizam. (2020). Landasan Pendidikan. Bandung: Pustaka Setia.

Safarati, dkk., (2020). "Pelatihan Inovasi Pembelajaran Mengahadapi Masa Pandemic Covid-19." Jurnal IImu Pendidikan. Vol. 01, No. 03. Hal. 240-243.

Tanzeh, A. (2011). Metodologi Penelitian Praktis. Yogyakarta: Teras. 